\title{
地球惑星・環境科学と 高校理科教育
}

木村 学・西山忠男・佐々木 晶・堀利栄

\section{はじめに}

2005年日本学術会議は再編された。その際 に、地球と太陽・惑星系研究を対象としていた 幾つかの研究連絡会は、第三部地球惑星科学委 員会として統合された。それと機を一にして、 研究連絡会金下の学会群も日本地球惑星科学連 合（以下連合）として自ら集約した。連合はそ の発足において、単なる学会間の連絡調整機能 だけではなく、それまで、地球物理学、地質学、 鉱物学、地理学などに分かれていた分野の研究 と教育も一層融合させることを意識して活動を 進めることした。それ以降、この10年間に共 同の年大会の開催、ニュースレターの発行、オー プンアクセス国際雑誌の発行開始、提言の発信、 国際合同大会の開催と着実に前進してきた。

地球惑星科学は、地震 · 火山・津波 ·風水害 などの自然災害をもたらす自然現象の科学的解 明を研究対象に含む。更に地球人口の急増に伴 う地球環境劣化、温暖化現象など地球環境変化 の理解にとって本質的な長短期的な地球システ 公間の相互作用、物質エネルギー循環の科学的 解明を研究目的の根幹に置く科学でもある。こ のことは、この新しく定義された地球惑星科学 は、人類がこの地球上で生き抜き、持続可能で 安定的な社会を設計構築していく上で欠かせな い基礎的知識体系であることを意味している。

日本学術会議地球惑星科学委員会と日本地球
惑星科学連合は、発足以来、自らの科学分野に ついて、「真理の探究」という知的探究目的は もちろんのこと、上に述べた「社会的責務」も 強く意識して学界活動を展開してきた。その過 程で、現在の初等・中等・高等教育と生涯教育 を通じて国民が身につけるべき科学リテラシー の向上が喫緊の課題であることを強調し、幾つ かの提言をしてきた。

本論では、それらについてレビューすると共 に、今後の検討すべき課題についても論じたい。

\section{これまでの提言・現状・課題}

日本地球惑星科学連合は、2005年、発足と同 時に「すべての高校生が学ぶべき地球人の科学 リテラシー一高等学校『理科』における全員必 修科目の創設とその内容に関する提言一」を発 表した。2007年にはそれをより具体化した「す べての高校生が学ぶべき地球人の科学リテラ シー一高等学校『理科』における全員必修科目 精選『教養理科（仮称)』の提案」*を発表。中 央教育審議会に提出した。

この提案の背景には、上に述べた研究対象を 持つ地球惑星科学あるいは地球環境科学は、自 然災害や地球環境問題に直面する社会や人間が 安心・安全に生きるために必要な基礎知識を提 供していることにある。更にその研究において は、これまでの高校理科の「物理・化学・生物 
学・地学」の全てを基礎知識として必要とする 総合科学であるということにもある。

高校理科教育が選択制となり、上記の基礎知 識を教育する「地学」は理系進学者ではほとん ど履修されないこと、それが長く続いたために 教育にあたる専門教員も極端に枯渇するに至っ ているなど、国民の自然災害や地球環境に関わ るリテラシーは大きく低下している。

日本学術会議地球惑星科学委員会は、2011年 3月 11 日に発生した東日本大震災を受けて発信 した提言「これからの地球惑星科学と社会の関 わり方について一東北地方太平洋沖地震 ·津波・ 放射性物質拡散問題からの教訓」(2014年 9月) の中でもリテラシーの向上と人材育成の重要性 を強調している。

日本学術会議科学者委員会・科学と社会委員 会合同、広報・科学力増進分科会は、地球惑星 科学分野のみならず、これまでの様々な分野で の議論を包括し、現状を分析したうえで、国民 の科学リテラシーを抜本強化するための「これ からの高校理科教育のあり方」(2016年2月）** を提案するに至った。

この提言は、これまでに比べてょり強く後期 中等教育での「理科基礎（仮称）」の必修科目設 置を提唱し、国民の科学リテラシー向上を訴え ている。その教育の後に当面「物理・化学・生 物学・地学」の積み上げを提案しているが、そ の壁はできるだけ低くし、近い将来は垣根を取 り払う方向をめざすのが良いことも記している。

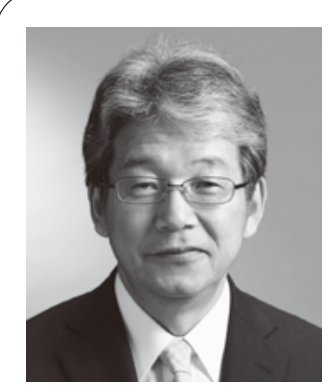

\section{PROFILE}

木村学

(きむら がく)

日本学術会議第三部会員、東京海洋大 学学術研究院特任教授

専門 : テクトニクス・構造地質学

\section{PROFILE}

西山忠男

(にしやま ただお)

日本学術会議連携会員、熊本大学先端 科学研究部理学系教授

専門 : 岩石学

\section{PROFILE}

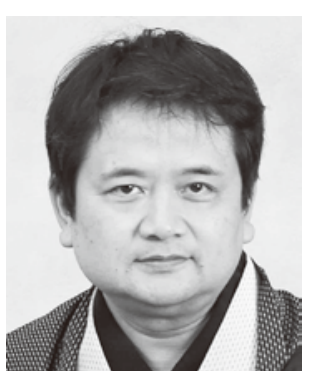

佐々木晶

(ささき しょう)

日本学術会議連携会員、大阪大学理学

研究科教授

専門: 惑星科学

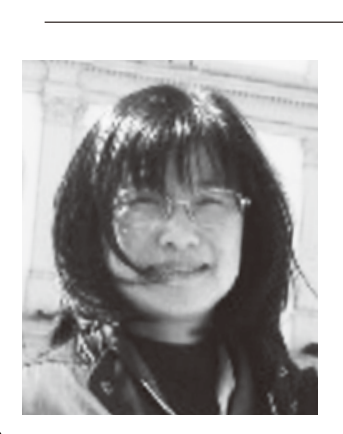

\section{PROFILE}

堀利栄

(ほりりえ)

日本学術会議連携会員、愛媛大学理工 学研究科教授

専門：地質・古生物学

日本学術会議地球惑星科学委員会社会貢献 分科会でも、第 21 期、第 22 期と人材育成の議 論を蓄積してきた。第21期には、国民のリテ ラシーを向上させるための地球惑星・環境科学 分野の検定制度がありうるのではないかとの議 
論を蓄積し、コミュニティーに波紋を投げ掛け た。また第22期には、大学受験に際して、大 学検定制度に似た単位取得制度の議論を蓄積 し、記録として残している。

日本地球惑星科学連合は、高校理科の全科目 を必修化するよう2016年7月に提案した。

また、日本学術会議地球惑星科学委員会は第 23期、これまで社会貢献分科会の中で検討して きた人材育成の課題を独立させ、人材育成分科 会を設置することにした。その中に、初等・中 等・生涯教育を検討するワーキンググループと 高等教育を検討するワーキンググループを設け て議論をすすめている。

人材育成分科会では検討すべき点として以下 の課題を挙げている。

初等・中等・高等教育全体を見渡した体系 の中での

（1）理科教科：「理科基礎（仮称）」内容の 検討。特に地球惑星、地球環境に関わ る基礎知識について。

（2）「理科基礎（仮称）」後の物理、化学、 生物学、地学の将来的再編成を見越し た「地学」内容の検討について。

（3）社会科「地理」と理科「地学」の融合 と切り分けについて

（4）国民の地球惑星、地球環境に関わる科 学リテラシーの日常的向上策と生涯教 育について

（5）後期中等教育と高等教育をシームレス につなぐための「高大連携」のあり方
について

（6）大学入試「地学」の改善方向について

\section{高校地学と地学入試問題}

以上、検討すべき課題は多岐にわたるが、深 刻な現状にある高校「地学」と地学入試問題に ついて、やや詳しく論ずる。

高校理科教育において地学が軽視されている 現状は、平成 24 年度に高等学校学習指導要領 が改訂されてからもあまり改善されていない。 新学習指導要領では、理科 4 基礎科目から 3 基 礎科目を履修するように改訂され、確かに地 学基礎の履修率は増加している（前学習指導 要領時代に地学Iと II合わせて $9.3 \%$ の履修率で あったのが、地学基礎だけで $27.6 \%$ に増加して いる**。しかし、履修者の大半は文系の生徒で あるようである。その理由はひとえに、各大学 の理系学部で地学を受験科目に加えている学部 が少ないことに起因するだろう。

九州の地方中核国立大学 K大学の事例を見て みよう。K大学理学部は平成 16 年度より全国に 先駆けて理学部理学科 1 学科制を採用した。入 試科目に地学は含まれているが、選択者は毎年 数名程度である（定員 190 名、倍率 2.4 倍程度)。 地学選択者が 0 名で、地元新聞に大きく報じら れたこともある。大学受験において「地学は潰 しがきかない」と思われているのであろう。こ の現状を変えるためには、工学部や農学部の受 験科目に地学を加えてもらう以外にはない。実 
際に教育学部や農学部での受験科目に加えた 四国のE大学では、地学受験者の増加が見られ た。自然災害が多発する我が国において、地学 は国民の命と財産を守るための基礎知識として 重要な学問であることを認識してもらい、理系 の生徒にも履修の道を開いてもらうことが必要 である。

\section{おわりに}

以上、検討すべき課題は多岐にわたるが、地 球惑星科学コミュニティーでは、これからの国 際・日本社会を展望しつつ、全国民のリテラシー の向上を見据えて、この分野の教育・人材育成 について議論を活性化し、理念から実行に至る までの、シームレスな方針を持ちたいと考えて いる。

参考文献

* 日本地惑星連合科学連合：

http://www.jpgu.org/education/20070928_doc.html

** 日本学術会議

http://www.scj.go.jp/ja/info/kohyo/pdf/kohyo-23-t224-1.pdf 